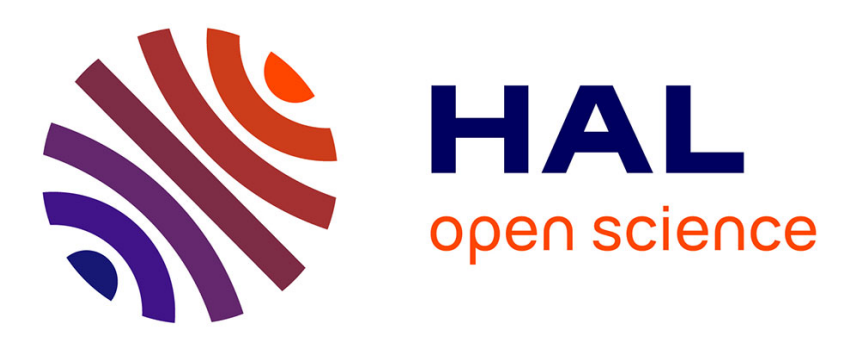

\title{
Aryl Grignard cross-coupling of aryl chlorides catalysed by new, highly active phosphine/imidazolium nickel(II) complexes
}

Joffrey Wolf, Agnès Labande, Michael Natella, Jean-Claude Daran, Rinaldo Poli

\section{To cite this version:}

Joffrey Wolf, Agnès Labande, Michael Natella, Jean-Claude Daran, Rinaldo Poli. Aryl Grignard cross-coupling of aryl chlorides catalysed by new, highly active phosphine/imidazolium nickel(II) complexes. Journal of Molecular Catalysis A: Chemical, 2006, 259 (1-2), pp.205-212. 10.1016/j.molcata.2006.06.004 . hal-03195883

\section{HAL Id: hal-03195883 \\ https://hal.science/hal-03195883}

Submitted on 12 Apr 2021

HAL is a multi-disciplinary open access archive for the deposit and dissemination of scientific research documents, whether they are published or not. The documents may come from teaching and research institutions in France or abroad, or from public or private research centers.
L'archive ouverte pluridisciplinaire HAL, est destinée au dépôt et à la diffusion de documents scientifiques de niveau recherche, publiés ou non, émanant des établissements d'enseignement et de recherche français ou étrangers, des laboratoires publics ou privés. 


\section{Aryl Grignard Cross-Coupling of Aryl Chlorides Catalysed by New, Highly Active Phosphine/Imidazolium Nickel(II) Complexes}

Joffrey Wolf, Agnès Labande*, Michael Natella, Jean-Claude Daran and Rinaldo Poli*

Laboratoire de Chimie de Coordination, UPR CNRS 8241 (lié par convention à l'Université

Paul Sabatier et à l'Institut National Polytechnique de Toulouse), 205 route de Narbonne, 31077 Toulouse Cedex 4, France.

Proofs to:

Dr. Agnès Labande

Tel: +33561333173

Fax: +33561553003

E-mail: labande@lcc-toulouse.fr 


\begin{abstract}
Two new zwitterionic Nickel(II) complexes, bearing phosphine/imidazolium ligands, have been prepared. Their catalytic activity, and the activity of an analogous $\mathrm{Ni}$ (II) complex, previously described by us, has been evaluated with a range of aryl chlorides, an aryl bromide and arylmagnesium halides. The catalytic activity is related to the length of the tether between the carbene and phosphine moieties. Thus the catalysts possessing a 6-membered metallacycle are more active than that having a 7-membered metallacycle. Changing from a mesityl (Mes) to a 2,6-diisopropylphenyl (DIP) on the imidazole ring does not strongly influence the activity. The three complexes show moderate to very good activities with most substrates, and enhanced selectivities compared to previously published $\mathrm{Ni}(\mathrm{II}) / N$-heterocyclic carbene systems. The low activity observed with 4-chlorobenzotrifluoride seems to be related to the presence of a phosphine on the ligands.
\end{abstract}

\title{
Keywords
}

Nickel, Phosphine, $N$-heterocyclic carbene, C-C coupling, Grignard 


\section{Introduction}

The development of very active, yet robust catalysts for application to organic synthesis is still a challenge. Complexes bearing $N$-heterocyclic carbenes are actively studied nowadays, because of their high thermal stability, and because metal-NHC bonds have high dissociation energies [1-3]. On the other hand, phosphine complexes of nickel(II) are very active in the $\mathrm{C}-\mathrm{C}$ coupling reaction between aryl halides and aryl Grignard reagents (KumadaCorriu reaction), but it is not rare to observe some ligand dissociation [4-11]. Consequently, mixed phosphine/N-heterocyclic carbene nickel complexes should be good candidates as catalysts for $\mathrm{C}-\mathrm{C}$ coupling reactions [12-17]. To date, only two $\mathrm{Ni}(\mathrm{II}) / \mathrm{N}$-heterocyclic carbene systems have been successfully tested in the reaction of aryl chlorides with aryl Grignard reagents [18].

We have recently described the preparation of two zwitterionic nickel(II) complexes, bearing a phosphine/imidazolium ligand (1a and 1d) [19]. These complexes proved very active as precatalysts for the coupling of phenylmagnesium chloride and 4-chloroanisole, giving an essentially total conversion of the starting aryl chloride after $1 \mathrm{~h}$ at room temperature, with only $3 \mathrm{~mol} \%$ of precatalyst.

Based on these results, we wanted to further explore the field and study the scope and limitations of our systems in the Kumada-Corriu reaction. In the present paper, we describe the preparation and characterisation of two new members of this family of nickel(II) phosphine-imidazolium complexes, and the evaluation of their catalytic activity with a range of aryl chlorides, one aryl bromide and arylmagnesium halides.

\section{Experimental}




\subsection{General comments}

All reactions were carried out under a dry argon atmosphere using Schlenk glassware and vacuum line techniques. Solvents for syntheses were dried and degassed by standard methods before use. Elemental analyses were carried out by the analytical service of the Laboratoire de Chimie de Coordination in Toulouse.

${ }^{1} \mathrm{H}$ data were recorded on Bruker AC200, AM-250 and AV-500 spectrometers, operating at 200, 250 and $500 \mathrm{MHz}$, respectively. ${ }^{13} \mathrm{C}\{\mathrm{H}, \mathrm{P}\}$ and ${ }^{31} \mathrm{P}\{\mathrm{H}\}$ NMR data were recorded on the Bruker AV-500 instrument, operating at 125.8 and $202.5 \mathrm{~Hz}$ respectively. The spectra were referenced internally using the signal from the residual protiosolvent $\left({ }^{1} \mathrm{H}\right)$ or the solvent signals $\left({ }^{13} \mathrm{C}\right)$, and externally using $85 \% \mathrm{H}_{3} \mathrm{PO}_{4}$ for ${ }^{31} \mathrm{P}$. Mass spectra were obtained from acetonitrile or methanol solutions on a TSQ7000 instrument from ThermoElectron (electrospray ionisation or chemical ionisation), and from DMSO or DMF solutions on a Nermag R10-10 instrument (FAB). GC chromatograms were recorded on a Fisons 8000 Series GC equipped with a SPB-5 capillary column and the products were identified by comparison with authentic samples. Commercial chemicals were from Acros, Aldrich, Alfa Aesar, Avocado or Fluka and used as received. $N$-(2,4,6-trimethylphenyl)imidazole $2 \mathbf{a}$ and $N$ (2,6diisopropylphenyl)imidazole $\mathbf{2 b}$ were prepared as described by Arduengo [20] and Johnson [21]. Compound 1a was synthesised as previously described [19].

\subsection{Synthesis of ligands}

\section{1-(2-hydroxyethyl)-3-(2,6-diisopropylphenyl)-imidazolium bromide $3 \boldsymbol{b}$}


2-Bromoethanol $(2.5 \mathrm{~mL}, 35 \mathrm{mmol})$ was added to a toluene solution $(150 \mathrm{~mL})$ of $\mathbf{2 b}(6.2$ g, $27.2 \mathrm{mmol}$ ). The mixture was stirred at $120^{\circ} \mathrm{C}$ for $20 \mathrm{~h}$. During this time a yellow-orange oil separated out in the flask. The mixture was cooled to room temperature and the toluene phase was removed. The oil was extracted with $\mathrm{CH}_{2} \mathrm{Cl}_{2}(20 \mathrm{~mL})$, the resulting solution was slowly precipitated in ether $(400 \mathrm{~mL})$, and the pale yellow solid which formed was filtered and dried in vacuo. Yield: $6.83 \mathrm{~g}(72 \%) .{ }^{1} \mathrm{H}$ NMR $\left(\delta, 500 \mathrm{MHz}, \mathrm{CDCl}_{3}\right): 9.50(\mathrm{~s}, 1 \mathrm{H}, \mathrm{N}-\mathrm{CH}-$ N), $8.19(\mathrm{~s}, 1 \mathrm{H},(\mathrm{DIP}) \mathrm{N}-\mathrm{CH}=\mathrm{C}), 7.38$ (t, J = 7.9 Hz, 1H, p-CH (DIP)), 7.15 (d, J = $7.9 \mathrm{~Hz}, 2 \mathrm{H}$, $m$-CH (DIP)), 7.09 (s, 1H, AlkN-CH=C), 4.73 (t, J = 4.8 Hz, 2H, N-CH2), 3.96 (br, 1H, OH), $3.84\left(\mathrm{t}, \mathrm{J}=4.8 \mathrm{~Hz}, 2 \mathrm{H}, \mathrm{CH}_{2}-\mathrm{OH}\right), 2.15\left(\mathrm{~h}, \mathrm{~J}=6.8 \mathrm{~Hz}, 2 \mathrm{H}, \mathrm{C} \underline{\mathrm{H}}-\left(\mathrm{CH}_{3}\right)_{2}\right), 1.01(\mathrm{~d}$ of d, J = 6.8 $\left.\mathrm{Hz}, 12 \mathrm{H}, \mathrm{CH}-\left(\mathrm{C}_{3}\right)_{2}\right) ;{ }^{13} \mathrm{C} \mathrm{NMR}\left(\delta, 125.8 \mathrm{MHz}, \mathrm{CDCl}_{3}\right): 145.35$ (o-C (DIP)), 137.63 (N-CHN), 131.75 (p-CH (DIP)), 130.00 (N-C (DIP)), 124.50 (m-CH (DIP)), 124.31 ((DIP)N-CH=), $123.73(\mathrm{AlkN}-\mathrm{CH}=), 60.17\left(\mathrm{CH}_{2}-\mathrm{OH}\right), 52.01\left(\mathrm{CH}_{2}-\mathrm{N}\right), 28.43\left(\mathrm{C} \underline{\mathrm{H}}-\left(\mathrm{CH}_{3}\right)_{2}\right), 24.33(\mathrm{CH}-$ $\left.\left(\mathrm{CH}_{3}\right)_{2}\right), 24.00\left(\mathrm{CH}-\left(\mathrm{C}_{3}\right)_{2}\right) . \mathrm{Mp} 169-170^{\circ} \mathrm{C}$. Anal. cal. for $\mathrm{C}_{17} \mathrm{H}_{25} \mathrm{BrN}_{2} \mathrm{O} ; \mathrm{C}: 57.79, \mathrm{H}: 7.13$, $\mathrm{N}: 7.93 \%$; found: C: 57.54, H: 6.90, N: 7.79\%. MS (ESI) m/z, (\%): 273.15, (100) $\left[\mathrm{C}_{17} \mathrm{H}_{25} \mathrm{~N}_{2} \mathrm{O}\right.$ $+] ; 79,(100)\left[\mathrm{Br}^{-}\right]$.

\section{1-(3-hydroxy-n-propyl)-3-(2,4,6-trimethylphenyl)imidazolium bromide 3c}

3-Bromo-1-propanol (2.2 mL, $24.0 \mathrm{mmol})$ was added to a toluene solution $(60 \mathrm{~mL})$ of $\mathbf{2 a}$ (3.72 $\mathrm{g}, 20.0 \mathrm{mmol})$. The mixture was stirred at $120^{\circ} \mathrm{C}$ for $15 \mathrm{~h}$. During this time a cream solid precipitated in the flask. The suspension was cooled to room temperature, the solid was decanted, washed with toluene $(2 \times 15 \mathrm{~mL})$ and dried in vacuo. A white solid was obtained. Yield: $4.47 \mathrm{~g}(69 \%) .{ }^{1} \mathrm{H}$ NMR $\left(\delta, 250 \mathrm{MHz}, \mathrm{CDCl}_{3}\right): 9.64$ (s, 1H, N-CH-N), 7.97 (t, J = 1.5 $\mathrm{Hz}, 1 \mathrm{H}, \mathrm{MesN}-\mathrm{CH}=\mathrm{C}), 7.16$ (t, J = $1.5 \mathrm{~Hz}, 1 \mathrm{H}, \mathrm{AlkN}-\mathrm{CH}=\mathrm{C}), 6.99$ (s, 2H, CH (Mes)), 4.85 (t, $\left.\mathrm{J}=4.9 \mathrm{~Hz}, 2 \mathrm{H}, \mathrm{N}-\mathrm{CH}_{2}\right), 4.03\left(\mathrm{t}, \mathrm{J}=4.8 \mathrm{~Hz}, 2 \mathrm{H}, \mathrm{CH}_{2}-\mathrm{O}\right), 3.54(\mathrm{br}, 1 \mathrm{H}, \mathrm{OH}), 2.33(\mathrm{~s}, 3 \mathrm{H}, p-$ 
$\left.\mathrm{CH}_{3}\right), 2.21\left(\mathrm{q}, \mathrm{J}=5.7 \mathrm{~Hz}, 2 \mathrm{H}, \mathrm{C}-\mathrm{CH}_{2}-\mathrm{C}\right), 2.07\left(\mathrm{~s}, 6 \mathrm{H}, o-\mathrm{CH}_{3}\right) . \mathrm{MS}\left[\mathrm{DCI}\left(\mathrm{NH}_{3}\right)\right] \mathrm{m} / \mathrm{z},(\%)$ :

245.2, (100) $\left[\mathrm{C}_{15} \mathrm{H}_{21} \mathrm{~N}_{2} \mathrm{O}^{+}\right] ; 79.2,(100)\left[\mathrm{Br}^{-}\right]$.

\section{1-(2-bromoethyl)-3-(2,6-diisopropylphenyl)imidazolium bromide $\mathbf{4 b}$}

$\mathrm{PBr}_{3}(0.83 \mathrm{~mL}, 8.80 \mathrm{mmol})$ was slowly added to a cold $\mathrm{CH}_{2} \mathrm{Cl}_{2}$ solution $\left(70 \mathrm{~mL}, 0^{\circ} \mathrm{C}\right)$ of 3b $(2.59 \mathrm{~g}, 7.33 \mathrm{mmol})$. The mixture was stirred for $20 \mathrm{~h}$ at room temperature, diluted with $\mathrm{CH}_{2} \mathrm{Cl}_{2}(70 \mathrm{~mL})$ and added to a cold, saturated $\mathrm{NaHCO}_{3}$ solution $\left(35 \mathrm{~mL}, 0^{\circ} \mathrm{C}\right)$. The organic phase was extracted and washed with a cold, saturated $\mathrm{NaHCO}_{3}$ solution $\left(1 \mathrm{x} 10 \mathrm{~mL}, 0^{\circ} \mathrm{C}\right)$. Subsequently, it was dried $\left(\mathrm{MgSO}_{4}\right)$, filtered and the solvent was removed in vacuo to give a white solid. Yield: $2.38 \mathrm{~g}(78 \%) .{ }^{1} \mathrm{H} \mathrm{NMR}\left(\delta, 500 \mathrm{MHz}, \mathrm{CDCl}_{3}\right): 10.07$ (t, J = 1.6 Hz, 1H, NCH-N), 8.67 (t, J = 1.6 Hz, 1H, (DIP)N-CH=C), 7.44 (t, J = 7.9 Hz, 1H, p-CH (DIP)), 7.20 (d, $\mathrm{J}=7.9 \mathrm{~Hz}, 2 \mathrm{H}, m-\mathrm{CH}(\mathrm{DIP})), 7.13(\mathrm{t}, \mathrm{J}=1.6 \mathrm{~Hz}, 1 \mathrm{H}, \mathrm{AlkN}-\mathrm{CH}=\mathrm{C}), 5.15(\mathrm{t}, \mathrm{J}=5.4 \mathrm{~Hz}, 2 \mathrm{H}$, $\left.\mathrm{N}-\mathrm{CH}_{2}\right), 3.96\left(\mathrm{t}, \mathrm{J}=5.4 \mathrm{~Hz}, 2 \mathrm{H}, \mathrm{CH}_{2}-\mathrm{Br}\right), 2.23\left(\mathrm{~h}, \mathrm{~J}=6.8 \mathrm{~Hz}, 2 \mathrm{H}, \mathrm{C} \underline{\mathrm{H}}-\left(\mathrm{CH}_{3}\right)_{2}\right), 1.09$ (d, J = $\left.6.8 \mathrm{~Hz}, 12 \mathrm{H}, \mathrm{CH}-\left(\mathrm{CH}_{3}\right)_{2}\right), 1.05\left(\mathrm{~d}, \mathrm{~J}=6.8 \mathrm{~Hz}, 12 \mathrm{H}, \mathrm{CH}-\left(\mathrm{CH}_{3}\right)_{2}\right) ;{ }^{13} \mathrm{C} \mathrm{NMR}(\delta, 125.8 \mathrm{MHz}$, $\left.\mathrm{CDCl}_{3}\right): 145.35(o-\mathrm{C}(\mathrm{DIP})), 138.21(\mathrm{~N}-\mathrm{CH}-\mathrm{N}), 131.85(p-\mathrm{CH}(\mathrm{DIP})), 129.98$ (N-C (DIP)), 124.57 (m-CH (DIP)), $124.39((\mathrm{DIP}) \mathrm{N}-\mathrm{CH}=), 123.94(\mathrm{AlkN}-\mathrm{CH}=), 50.73\left(\mathrm{CH}_{2}-\mathrm{N}\right), 32.00$ $\left(\mathrm{CH}_{2}-\mathrm{Br}\right), 28.50\left(\mathrm{C} \underline{\mathrm{H}}-\left(\mathrm{CH}_{3}\right)_{2}\right), 24.47\left(\mathrm{CH}-\left(\mathrm{C}_{3}\right)_{2}\right), 24.00\left(\mathrm{CH}-\left(\mathrm{C}_{3}\right)_{2}\right) . \mathrm{Mp} 73-75^{\circ} \mathrm{C}$. Anal. cal. for $\mathrm{C}_{17} \mathrm{H}_{24} \mathrm{Br}_{2} \mathrm{~N}_{2}$; C: 49.06, H: 5.81, N: $6.73 \%$; found: C: 48.71, H: 6.11, N: 6.43\%. MS (ESI) m/z, (\%): 335, (100) $\left[\mathrm{C}_{17} \mathrm{H}_{24} \mathrm{BrN}_{2}{ }^{+}\right] ; 79,(100)\left[\mathrm{Br}^{-}\right]$.

\section{1-(3-bromo-n-propyl)-3-(2,4,6-trimethylphenyl)imidazolium bromide $4 \boldsymbol{c}$}

$\mathrm{PBr}_{3}(1.1 \mathrm{~mL}, 11.5 \mathrm{mmol})$ was slowly added to a cold $\mathrm{CH}_{2} \mathrm{Cl}_{2}$ solution $\left(80 \mathrm{~mL}, 0^{\circ} \mathrm{C}\right)$ of $\mathbf{3 c}$ ( $3.26 \mathrm{~g}, 10 \mathrm{mmol}$ ). The mixture was stirred for $15 \mathrm{~h}$ at room temperature, diluted with $\mathrm{CH}_{2} \mathrm{Cl}_{2}$ $(80 \mathrm{~mL})$ and added to a cold, saturated $\mathrm{NaHCO}_{3}$ solution $\left(25 \mathrm{~mL}, 0^{\circ} \mathrm{C}\right)$. The organic phase was extracted and washed with cold, saturated $\mathrm{NaHCO}_{3}\left(1 \times 10 \mathrm{~mL}, 0^{\circ} \mathrm{C}\right)$. Subsequently, it 
was dried $\left(\mathrm{MgSO}_{4}\right)$, filtered and the solvent was removed in vacuo to give a pale yellow solid. Yield: $3.37 \mathrm{~g}(87 \%) .{ }^{1} \mathrm{H}$ NMR $\left(\delta, 500 \mathrm{MHz}, \mathrm{CDCl}_{3}\right): 10.23(\mathrm{~s}, 1 \mathrm{H}, \mathrm{N}-\mathrm{CH}-\mathrm{N}), 8.23(\mathrm{~s}, 1 \mathrm{H}$, MesN-CH=C), 7.23 (s, 1H, AlkN-CH=C), 6.95 (s, 2H, CH (Mes)), 4.86 (t, J = 6.8 Hz, 2H, N$\mathrm{CH}_{2}$ ), 3.48 (t, J = $\left.6.3 \mathrm{~Hz}, 2 \mathrm{H}, \mathrm{CH}_{2}-\mathrm{Br}\right), 2.63$ (q, J = 5.2 Hz, 2H, C-CH2-C), 2.29 (s, 3H, p$\left.\mathrm{CH}_{3}\right), 2.02\left(\mathrm{~s}, 6 \mathrm{H}, o-\mathrm{CH}_{3}\right) ;{ }^{13} \mathrm{C} \mathrm{NMR}\left(\delta, 125.8 \mathrm{MHz}, \mathrm{CDCl}_{3}\right): 141.28$ (p-C (Mes)), $137.78(\mathrm{~N}-$ CH-N), 134.10 (o-C (Mes)), 130.62 (N-C (Mes)), 129.85 (CH (Mes)), 124.04 (AlkN-CH=), $123.39(\mathrm{MesN}-\mathrm{CH}=), 48.79\left(\mathrm{~N}-\mathrm{CH}_{2}\right), 33.01\left(\mathrm{C}-\mathrm{CH}_{2}-\mathrm{C}\right), 29.13\left(\mathrm{CH}_{2}-\mathrm{Br}\right), 21.11\left(p-\mathrm{CH}_{3}\right)$, $17.72\left(o-\mathrm{CH}_{3}\right) . \mathrm{Mp} 148-149^{\circ} \mathrm{C}$. Anal. cal. for $\mathrm{C}_{15} \mathrm{H}_{20} \mathrm{Br}_{2} \mathrm{~N}_{2} ; \mathrm{C}: 46.42, \mathrm{H}: 5.19, \mathrm{~N}: 7.22 \%$; found: $\mathrm{C}: 46.30, \mathrm{H}: 4.92, \mathrm{~N}: 7.11 \%$. MS (ESI) m/z, (\%): 399, (100) $\left[\mathrm{C}_{15} \mathrm{H}_{20} \mathrm{BrN}_{2}{ }^{+}\right] ; 79-81$, (100) $\left[\mathrm{Br}^{-}\right]$.

\section{1-(2-diphenylphosphinoethyl)-3-(2,6-diisopropylphenyl)imidazolium bromide $\mathbf{5 b}$}

$\mathrm{KPPh}_{2}$, freshly made from $t$-BuOK $(337 \mathrm{mg}, 3.00 \mathrm{mmol})$ and $\mathrm{HPPh}_{2}(0.54 \mathrm{~mL}, 3.15$ mmol) in DMSO (8mL), was added to a DMSO solution (8 $\mathrm{mL})$ of $\mathbf{4 b}(1.19 \mathrm{~g}, 2.86 \mathrm{mmol})$. The solution was allowed to stir for $2 \mathrm{~h}$ at room temperature. The solvent was then removed under vacuum. Methanol (5 mL) was added to quench the excess $\mathrm{KPPh}_{2}$, then removed under vacuum. Dichloromethane $(10 \mathrm{~mL})$ was added and the resulting mixture was filtered and diethyl ether $(100 \mathrm{~mL})$ was added. The resulting precipitate was separated by filtration and dried in vacuo. The product was obtained as a white, air-sensitive solid. Yield: $1.37 \mathrm{~g} \mathrm{(92 \% ).}$ ${ }^{1} \mathrm{H}$ NMR $\left(\delta, 200 \mathrm{MHz}, \mathrm{CDCl}_{3}\right): 10.20$ (s, 1H, N-CH-N), 7.85 (s, 1H, MesN-CH=C), 7.46 (t, J $=7.8 \mathrm{~Hz}, 1 \mathrm{H}, p-\mathrm{CH}(\mathrm{DIP})), 7.39\left(\mathrm{~m}, 4 \mathrm{H}, o-\mathrm{CH}\left(\mathrm{C}_{6} \mathrm{H}_{5}\right)\right), 7.30\left(\mathrm{~m}, 6 \mathrm{H}, m / p-\mathrm{CH}\left(\mathrm{C}_{6} \mathrm{H}_{5}\right)\right), 7.23$ $(\mathrm{d}, \mathrm{J}=8 \mathrm{~Hz}, 2 \mathrm{H}, m-\mathrm{CH}(\mathrm{DIP})), 7.07(\mathrm{~s}, 1 \mathrm{H}, \mathrm{AlkN}-\mathrm{CH}=\mathrm{C}), 4.84(\mathrm{~d}$ of t $\mathrm{J}=12.4 \mathrm{~Hz}-\mathrm{J}=6.9$ $\left.\mathrm{Hz}, 2 \mathrm{H}, \mathrm{N}-\mathrm{CH}_{2}\right), 2.84\left(\mathrm{t}, \mathrm{J}=6.8 \mathrm{~Hz}, 2 \mathrm{H}, \mathrm{CH}_{2}-\mathrm{P}\right), 2.25\left(\mathrm{~h}, \mathrm{~J}=6.8 \mathrm{~Hz}, 2 \mathrm{H}, \mathrm{C} \underline{\mathrm{H}}-\left(\mathrm{CH}_{3}\right)_{2}\right), 1.17$ $\left(\mathrm{d}, \mathrm{J}=6.6 \mathrm{~Hz}, 6 \mathrm{H}, \mathrm{CH}-\left(\mathrm{C}_{3}\right)_{2}\right), 1.07\left(\mathrm{~d}, \mathrm{~J}=6.9 \mathrm{~Hz}, 6 \mathrm{H}, \mathrm{CH}-\left(\mathrm{C}_{3}\right)_{2}\right) ;{ }^{31} \mathrm{P} \mathrm{NMR} \quad(\delta, 81 \mathrm{MHz}$, $\left.\mathrm{CDCl}_{3}\right)$ : -20.77 $\left(\mathrm{CH}_{2}-\mathrm{PPh}_{2}\right)$ (data consistent with those found in the literature [13]). 


\section{1-(3-diphenylphosphinopropyl)-3-(2,4,6-trimethylphenyl)imidazolium bromide 5 c}

$\mathrm{KPPh}_{2}$, freshly made from $t$-BuOK $(152 \mathrm{mg}, 1.35 \mathrm{mmol})$ and $\mathrm{HPPh}_{2}(0.25 \mathrm{~mL}, 1.42$ $\mathrm{mmol})$ in DMSO (3mL), was added to a DMSO solution (2 mL) of $4 \mathbf{c}(500 \mathrm{mg}, 1.29 \mathrm{mmol})$. The solution was allowed to stir for $15 \mathrm{~h}$ at room temperature. The solvent was then removed under vacuum. Methanol (5 mL) was added to quench the excess $\mathrm{KPPh}_{2}$, then removed under vacuum. Dichloromethane $(10 \mathrm{~mL})$ was added and the resulting mixture filtered. The filtrate was concentrated (ca. $1.5 \mathrm{~mL})$ and diethyl ether $(20 \mathrm{~mL})$ was added. The resulting precipitate was separated by filtration and dried in vacuo. The product was obtained as a white, airsensitive solid. Yield: $500 \mathrm{mg}(79 \%) .{ }^{1} \mathrm{H} \mathrm{NMR}\left(\delta, 200 \mathrm{MHz}, \mathrm{CDCl}_{3}\right): 10.35$ (t, J = $1.7 \mathrm{~Hz}$, 1H, N-CH-N), 7.75 (t, J = 1.8 Hz, 1H, MesN-CH=C), $7.36\left(\mathrm{t}, \mathrm{J}=7.8 \mathrm{~Hz}, 1 \mathrm{H}, o-\mathrm{CH}\left(\mathrm{C}_{6} \mathrm{H}_{5}\right)\right)$, $7.28\left(\mathrm{~m}, 6 \mathrm{H}, \mathrm{m} / p-\mathrm{CH}\left(\mathrm{C}_{6} \mathrm{H}_{5}\right)\right), 7.16(\mathrm{t}, \mathrm{J}=1.7 \mathrm{~Hz}, 1 \mathrm{H}, \mathrm{AlkN}-\mathrm{CH}=\mathrm{C}), 6.92(\mathrm{~s}, 2 \mathrm{H}, \mathrm{CH}(\mathrm{Mes}))$, $4.76\left(\mathrm{~d}\right.$ of $\left.\mathrm{t}, \mathrm{J}=25.6 \mathrm{~Hz}-\mathrm{J}=6.5 \mathrm{~Hz}, 2 \mathrm{H}, \mathrm{N}-\mathrm{CH}_{2}\right), 2.97(\mathrm{~d}$ of $\mathrm{t}, \mathrm{J}=23 \mathrm{~Hz}-\mathrm{J}=6.5 \mathrm{~Hz}, 2 \mathrm{H}$, $\left.\mathrm{CH}_{2}-\mathrm{P}\right), 2.27\left(\mathrm{~s}, 3 \mathrm{H}, p-\mathrm{CH}_{3}\right), 2.63\left(\mathrm{~m}, 2 \mathrm{H}, \mathrm{C}-\mathrm{CH}_{2}-\mathrm{C}\right), 1.98\left(\mathrm{~s}, 6 \mathrm{H}, o-\mathrm{CH}_{3}\right) ;{ }^{31} \mathrm{P} \mathrm{NMR}(\delta, 81$ $\left.\mathrm{MHz}, \mathrm{CDCl}_{3}\right)$ : -14.1 (s, $\left.\mathrm{CH}_{2}-\mathrm{PPh}_{2}\right)$ (data consistent with those found in the literature [13]).

\section{3. Synthesis of Nickel(II) complexes:}

1-(2-diphenylphosphinoethyl)-3-(2,6-diisopropylphenyl)imidazolium nickel tribromide $\mathbf{1 b}$

$\mathrm{NiBr}_{2}$ (DME) (410 mg, $1.33 \mathrm{mmol}$ ) was added to a solution of $\mathbf{5 b}$ (700 $\left.\mathrm{mg}, 1.34 \mathrm{mmol}\right)$ in THF (20 mL). The mixture was stirred at room temperature for $30 \mathrm{~min}$ to give a green solution. The solvent was removed under vacuum and $\mathrm{CHCl}_{3}(20 \mathrm{~mL})$ was added. The mixture was filtered and the solvent removed to give a green solid. Yield: $953 \mathrm{mg}(97 \%) .{ }^{1} \mathrm{H}$ NMR ( $\left.\delta, 200 \mathrm{MHz}, \mathrm{CDCl}_{3}\right):{ }^{1} \mathrm{H}$ NMR ( $\delta, 250 \mathrm{MHz}, \mathrm{d}_{6}-(\mathrm{Me}){ }_{2} \mathrm{CO}$ ): 20.79 (br s), 7.05 (br s), 6.69 (br s), 6.13 (br s), 3.86 (br s), 2.94 (br s), 2.62 (br s), 1.30 (br s), 0.23 (br s), 0.07 (br s), 
-2.22 (br s); mp $157-159^{\circ} \mathrm{C}$. Anal. cal. for $\mathrm{C}_{29} \mathrm{H}_{34} \mathrm{Br}_{3} \mathrm{NiN}_{2} \mathrm{P}$; C: $47.07, \mathrm{H}: 4.63, \mathrm{~N}: 3.79 \%$; found: C: 46.72, $\mathrm{H}: 4.85, \mathrm{~N}: 3.59 \%$. MS (ESI) m/z, (\%): 441.6, (100) $\left[\mathrm{C}_{29} \mathrm{H}_{34} \mathrm{~N}_{2} \mathrm{P}^{+}\right] ; 79,(100)$ $\left[\mathrm{Br}^{-}\right]$.

\section{1-(3-diphenylphosphinopropyl)-3-(2,4,6-trimethylphenyl)imidazolium nickel tribromide 1c}

$\mathrm{NiBr}_{2}(\mathrm{MeCN})_{2}(312 \mathrm{mg}, 1.01 \mathrm{mmol})$ was added to a suspension of 5c $(435 \mathrm{mg}, 0.88$ $\mathrm{mmol})$ in THF $(10 \mathrm{~mL})$. The mixture was stirred at room temperature for $1 \mathrm{~h}$. The precipitate was filtered, the green solid/oil obtained was washed with THF (2 x $5 \mathrm{~mL}), \mathrm{CHCl}_{3}(2 \times 10$ $\mathrm{mL}$ ) and dried under vacuum to give a green solid. Yield: $612 \mathrm{mg}(97 \%)$. Green crystals were obtained by diffusion of diethyl ether into an acetonitrile solution. ${ }^{1} \mathrm{H}$ NMR $\left(\delta, 250 \mathrm{MHz}, \mathrm{d}_{6^{-}}\right.$ (Me) $)_{2} \mathrm{CO}$ ): 20.72 (br s), 8.81 (br s), 8.63 (br s), 7.92 (s), 7.23 (s), 6.13 (s), 6.02 (br s), 4.53 (br s), 3.94 (br s), 3.70 (br s), 2.39 (br s), 2.23 (br s), 1.86 (s), -0.34 (br s), -2.43 (br s); mp 226$227^{\circ}$ C. Anal. cal. for $\mathrm{C}_{27} \mathrm{H}_{30} \mathrm{Br}_{3} \mathrm{NiN}_{2} \mathrm{P}$; C: $45.55, \mathrm{H}: 4.25$, N: 3.93\%; found: C: 45.12, $\mathrm{H}: 3.95$, $\mathrm{N}: 3.79 \%$. MS (FAB, MNBA matrix) m/z, (\%): 413 (100) $\left[\mathrm{C}_{27} \mathrm{H}_{30} \mathrm{~N}_{2} \mathrm{P}^{+}\right] ; 631$ (0.5) $\left[\mathrm{C}_{27} \mathrm{H}_{30} \mathrm{Br}_{2} \mathrm{NiN}_{2} \mathrm{P}^{+}\right]$.

\subsection{Standard procedure for Kumada-Corriu reactions:}

The aryl halide $(1 \mathrm{mmol})$ and diethyleneglycol-di- $n$-butylether $(30 \mu \mathrm{L}$ as internal standard $)$ were mixed with $1 \mathbf{1 a}, \mathbf{1 b}$ or $\mathbf{1 c}(3 \mathrm{~mol} \%$ based on aryl halide) in THF (1 mL). The arylmagnesium halide $(1.5 \mathrm{mmol})$ was slowly added to the mixture. Reactions were kept at room temperature (between $23-25^{\circ} \mathrm{C}$ ) for $18 \mathrm{~h}$ and quenched with a minimum of ethanol. In order to remove the catalyst and the magnesium salt, mixtures were filtered on silica with ether as solvent. The resulting mixtures were analysed by gas chromatography.

\subsection{X-ray analyses:}


A single crystal was mounted under inert perfluoropolyether at the tip of a glass fibre and cooled in the cryostream of an Oxford-Diffraction XCALIBUR CCD diffractometer. Data were collected using the monochromatic MoK $\alpha$ radiation $(\lambda=0.71073)$. The Final unit cell parameters were obtained by the least-squares refinement of a large number of selected reflections. Only statistical fluctuations were observed in the intensity monitors over the course of the data collection.

The structure was solved by direct methods (SIR97 [22]) and refined by least-squares procedures on $F^{2}$ with the SHELXL-97 program [23] using the integrated system WINGX(1.63) [24]. Hydrogen atoms attached to carbon atoms were introduced at calculated positions and treated as riding on their parent atoms $[\mathrm{d}(\mathrm{CH})=0.96-0.98 \AA]$ with a displacement parameter equal to $1.2\left(\mathrm{C}_{6} \mathrm{H}_{5}, \mathrm{CH}_{2}, \mathrm{OH}\right)$ or $1.5\left(\mathrm{CH}_{3}\right)$ times that of the parent atom. Owing to the poor quality of the crystal, only reflections with theta below $23.3^{\circ}$ were used in the refinement procedure. The Molecular view was realised with the help of ORTEPIII [25]. Crystal data and refinement parameters are shown in Table 1.

Table 1.

Crystallographic data (excluding structure factors) have been deposited with the Cambridge Crystallographic Data Centre as supplementary publication no. CCDC 299074. Copies of the data can be obtained free of charge on application to the Director, CCDC, 12 Union Road, Cambridge CB2 1EZ, UK (fax: (+44) 1223-336-033; e-mail: deposit@ccdc.cam.ac.uk).

\section{Results and discussion}


Following our recent discovery that the nickel(II) complexes $\mathbf{1 a}$ and $\mathbf{1 d}$ are excellent precatalysts for the coupling of phenylmagnesium chloride and 4-chloroanisole [19], it was of interest to see whether small structural changes in the phosphine-imidazolium ligand could affect the properties or catalytic activity. For this purpose, we considered two modifications: (i) replacement of the ortho substituents on the aryl group of the imidazolium moiety by bulkier isopropyl substituents; (ii) an increased length of the tether from 2 to 3 carbons, thus forming a 7-membered metallacycle instead of a 6-membered one in the putative phosphinocarbene complex (Figure 1).

Ligands $\mathbf{5 b}$ and $\mathbf{5 c}$ were prepared by a natural extension of the procedure previously described for ligand 5a [19]. Thus, 2-bromoethanol reacted with $N$-(2,6diisopropylphenyl)imidazole to give imidazolium salt $\mathbf{3 b}$ in good yield. Analogously, the reaction of 3-bromopropanol with $\mathrm{N}$-mesitylimidazole gave imidazolium salt $\mathbf{3 c}$ in good yield (in this case, the procedure described by Fürstner [26] was slightly modified and allowed us to improve the yield from $28 \%$ to $69 \%$ ). Bromination of $\mathbf{3 b}$ and $\mathbf{3 c}$ with $\mathrm{PBr}_{3}$ gave compounds 4b and 4c. Finally, nucleophilic substitution with $\mathrm{KPPh}_{2}$ gave the expected imidazolium salts $\mathbf{5 b}$ and $\mathbf{5 c}$, with $\mathrm{Br}^{-}$as the anion, in good to excellent yields.

Zwitterionic nickel(II) complexes $\mathbf{1 b}$ and $\mathbf{1 c}$ were obtained, like the previously reported 1a [19], in excellent yields by stirring a mixture of the desired ligand and $\mathrm{NiBr}_{2} \mathrm{~L}_{2}$ for $1 \mathrm{~h}$ in THF at room temperature (Scheme 2). Like 1a, the two new complexes are green, paramagnetic compounds, with a distorted tetrahedral geometry. They have been characterized by NMR, elemental analysis and mass spectrometry, and by an X-Ray diffraction study for 1c (Figure 2). The paramagnetism is indicated by the large paramagnetic shift of certain resonances in the ${ }^{1} \mathrm{H}$ NMR spectrum. Unfortunately, we did not manage to isolate the corresponding carbenic $\mathrm{Ni}(\mathrm{II})$ complexes, obtained by deprotonation of the 
imidazolium moiety in the presence of $\operatorname{LiN}\left(\mathrm{SiMe}_{3}\right)_{2}$. However, the deprotonation of 1a-c induced a colour change to yellow-brown, consistent with the formation of diamagnetic, square-planar complexes. An NMR monitoring of the deprotonation of 1a confirmed the formation of nickel phosphine-carbene complexes. Indeed, the ${ }^{31} \mathrm{P}$ NMR spectrum shows two sharp, very close signals at $3.28 \mathrm{ppm}$ (major) and $2.99 \mathrm{ppm}$ (minor), in addition to a sharp signal at $-18.3 \mathrm{ppm}$ which could correspond to the free phosphine. In the ${ }^{13} \mathrm{C}$ NMR spectrum, two small doublets were observed in the typical region of coordinated NHC's at respectively $168.3 \mathrm{ppm}\left(\mathrm{J}_{\mathrm{PC}}=108.2 \mathrm{~Hz}\right)$ and $159.85 \mathrm{ppm}\left(\mathrm{J}_{\mathrm{PC}}=35.2 \mathrm{~Hz}\right)$. A selective ${ }^{31} \mathrm{P}$ decoupling experiment showed that these two doublets are coupled to the phosphorus nuclei resonating at 3.28 and/or $2.99 \mathrm{ppm}$, but not to the one at $-18.3 \mathrm{ppm}$. The presence of two doublets, with very different $\mathrm{J}_{\mathrm{PC}}$ coupling constants, could be explained by the formation of two carbenic complexes (Figure 1): a monomer, bearing the chelating carbene-phosphine ligand (cis coupling), and a dimer, with the carbene and the phosphine being in trans on the nickel. Moreover, we did not observe the characteristic ${ }^{1} \mathrm{H}$ NMR signal at ca. $10.5 \mathrm{ppm}$ corresponding to the acidic proton of the imidazolium moiety. The ${ }^{31} \mathrm{P}$ NMR spectrum of the deprotonation product of $1 \mathbf{c}$ shows a similar pattern, with two close singlets at -5.2 and -5.5 ppm, and a very small signal at $-15.0 \mathrm{ppm}$.

A view of compound $\mathbf{1 c}$ is illustrated in Figure 2. The $\mathrm{Ni}$ atom is tetrahedrally coordinated by the phosphorus atom of the phosphine group and by three bromine atoms. The $\mathrm{Ni}-\mathrm{P}$ distance is comparable with the value found in $\left[\mathrm{NiBr}_{3}\left(\mathrm{PPh}_{3}\right)\right]^{-}\left(\mathrm{C}_{24} \mathrm{H}_{20} \mathrm{As}\right)^{+}(2.323(1) \AA$ ) [27]. The Br atoms are rotationally staggered with respect to the phenyl and the imidazolium groups. The three $\mathrm{Br}-\mathrm{Ni}-\mathrm{Br}$ angles show a significant deviation from their mean, 112.8(1) ${ }^{\circ}$, with two values greater than the ideal tetrahedral angle. The mesityl group is found roughly orthogonal to the imidazolium ring with a dihedral angle of $88.2(4)^{\circ}$, as previously observed 
in $\left[1-\left(2,4,6-\mathrm{Me}_{3} \mathrm{C}_{6} \mathrm{H}_{2}\right)\right.$ imidazolium-3- $\left.\left\{\mathrm{CH}_{2} \mathrm{C}(t-\mathrm{Bu})=\mathrm{N}(i-\mathrm{Pr})\right\}\right]$ bromide [28]. The internal bond lengths and angles of the imidazolium ring are unexceptional and lie within the range expected [29]. It is interesting to note that there are three weak intermolecular $\mathrm{C}-\mathrm{H} \ldots \mathrm{Br}(1)$ hydrogen bond interactions (Table 2), the shortest one being with the acidic imidazolium proton.

The new complexes, together with the previously reported complex 1a, were tested as precatalysts for the coupling reaction between a variety of aryl chlorides and Grignard reagents, extending the previous study of the coupling of 4-chloroanisole with phenylmagnesium chloride catalyzed by 1a [19]. The corresponding trichloride complex 1d was not further investigated, because our previous study showed that the activity does not depend on the nature of the halide ligand. As we have previously shown [19], the catalytic results are independent on whether the Grignard reagent or an external base (e.g. $\left.\mathrm{LiN}\left(\mathrm{SiMe}_{3}\right)_{2}\right)$ is used to deprotonate the precatalysts. Therefore, we consider that a chelating phosphine-carbene coordination mode is present in the catalyst as indicated by the NMR results described above. The results are given in Table 3. A more detailed analysis of the product distribution yields the results shown in Tables 4 and 5.

Some general trends emerge from this work. Complex 1a, bearing a mesityl group on the imidazolium moiety, is a bit more active than 1b. Both complexes, with the notable exceptions of the couplings involving the $\mathrm{CF}_{3}$-substituted aryl chloride substrate (runs 2 and 8), also show an equal or slightly better activity than the Ni(acac)/IPr system [18], as can be seen from the kinetic studies (Figures 3 and 4). Indeed, in the reaction of 4-chloroanisole with phenylmagnesium chloride, the 4-chloroanisole conversion reached $95 \%$ with 1 a and $82 \%$ with $\mathbf{1 b}$ after $1 \mathrm{~h}$ (Figure 3). On the other hand, complex $\mathbf{1 b}$ was a bit more selective than $\mathbf{1 a}$ 
and gave less by-products (Tables 4 and 5) [30]. Both are more selective than the $\mathrm{Ni}(\mathrm{acac})_{2} / \mathrm{IPr}$ system.

In most cases, complex $\mathbf{1 c}$ showed a poorer activity than $\mathbf{1 a}$ or $\mathbf{1 b}$, as can be seen from Table 3 and Figure 3. It seems that the formation of a 7-membered cycle slows the reaction down. For several substrates, complex 1c also shows a reduced selectivity, even relative to the $\mathrm{Ni}(\mathrm{acac})_{2} / \mathrm{IPr}$ system.

One noticeable exception was observed with 4-chlorobenzotrifluoride, where conversions were low, with up to $71 \%$ starting material left for entry 2 (Table 4 ) and $66 \%$ for entry 8 (Table 5). A similar behaviour was reported for a monophosphine-based system, namely $\mathrm{Ni}(\mathrm{acac})_{2} / \mathrm{P}(t-\mathrm{Bu})_{3}$ (up to $53 \%$ starting material left), whereas the use of a simple imidazolium salt gave excellent conversions under the same conditions (Table 4, entry 2) [18]. A GC monitoring of this reaction provided insight as to the possible cause of this reduced activity.

The rate of conversion is initially high but dramatically drops after ca. $2 \mathrm{~h}$. This result clearly indicates that the catalyst is rather active at the early stages of the reaction but dies as the reaction progresses. This stability problem appears closely related to the simultaneous presence of $\mathrm{CF}_{3}$ groups and a phosphine in the ligand system.

Finally, the presence of ortho substituents relative to the chlorine atom had a dramatic effect on conversion with 1c, but a much less pronounced effect with $\mathbf{1 b}$. A curious effect, for which we cannot offer an obvious rationalization, is the significantly lower activity of $\mathbf{1 a}$ relative to $\mathbf{1 b}$ for entry 11 , whereas about the same activity of the two catalysts is observed for entry 5 . 


\section{Conclusion}

Zwitterionic complexes of $\mathrm{Ni}(\mathrm{II})$, bearing phosphine/imidazolium ligands, have been prepared and show high activities and selectivities for the coupling of aryl chlorides with aryl Grignard reagents at room temperature. We have observed that small structural changes, such as increasing the length of the ligand tether from 2 to 3 carbons, could have a dramatic effect on the catalytic activity. Very high conversions have been achieved, except in the case of 4chlorobenzotrifluoride, where the presence of a phosphine moiety in the catalyst seems to hamper the reaction. We are now studying the coordination chemistry of these ligands on other metals, and the catalytic properties of the resulting complexes will be tested in due course.

\section{Acknowledgements}

We are grateful to the CNRS for support of this work and to the "Fonds Social Européen" for a Ph.D. fellowship to JW.

[1] W.A. Herrmann, Angew. Chem., Int. Ed. Engl. 41 (2002) 1290.

[2] D. Bourissou, O. Guerret, F.P. Gabbai, G. Bertrand, Chem. Rev. 100 (2000) 39.

[3] K.J. Cavell, D.S. McGuinness, Coord. Chem. Rev. 248 (2004) 671.

[4] K. Tamao, K. Sumitani, M. Kumada, J. Am. Chem. Soc. 94 (1972) 4374.

[5] M. Kumada, Pure Appl. Chem. 52 (1980) 669.

[6] K. Tamao, J. Organomet. Chem. 653 (2002) 23.

[7] T. Banno, Y. Hayakawa, M. Umeno, J. Organomet. Chem. 653 (2002) 288.

[8] E. Wenkert, E.L. Michelotti, C.S. Swindell, M. Tingoli, J. Org. Chem. 49 (1984) 4894.

[9] L.N. Pridgen, J. Org. Chem. 47 (1982) 4319.

[10] A. Minato, K. Tamao, K. Suzuki, M. Kumada, Tetrahedron Lett. 21 (1980) 4017.

[11] J.W. Dankwardt, Angew. Chem., Int. Ed. Engl. 43 (2004) 2428.

[12] J. Huang, S.P. Nolan, J. Am. Chem. Soc. 121 (1999) 9889.

[13] N. Tsoureas, A.A. Danopoulos, A.A.D. Tulloch, M.E. Light, Organometallics 22 (2003) 4750.

[14] N. Stylianides, A.A. Danopoulos, N. Tsoureas, J. Organomet. Chem. 690 (2005) 5948.

[15] T. Focken, G. Raabe, C. Bolm, Tetrahedron: Asymmery 15 (2004) 1693.

[16] E. Bappert, G. Helmchen, Synlett (2004) 1789. 
[17] S. Gischig, A. Togni, Organometallics 23 (2004) 2479.

[18] V.P.W. Böhm, T. Weskamp, C.W.K. Gstöttmayr, W.A. Herrmann, Angew. Chem., Int. Ed. Engl. 39 (2000) 1602.

[19] J. Wolf, A. Labande, J.-C. Daran, R. Poli, J. Organomet. Chem. 691 (2006) 433.

[20] A. J. Arduengo III, F. P. Gentry Jr., P. K. Taverkere, H. E. Simmons Jr., U.S. Patent 6,177,575 (2001).

[21] A. L. Johnson, U.S. Patent 3,637,731 (1972).

[22] A. Altomare, M.C. Burla, M. Camalli, G.L. Cascarano, C. Giacovazzo, A. Guagliardi, A.G.G. Moliterni, G. Polidori, R. Spagna, SIR97 a program for automatic solution of crystal structures by direct methods. J. Appl. Cryst. 32 (1999), 115.

[23] G. M. Sheldrick, SHELX97, Programs for Crystal Structure Analysis (Release 97-2) (1998), Institüt für Anorganische Chemie der Universität, Tammanstrasse 4, D-3400 Göttingen, Germany.

[24] L.J. Farrugia, J. Appl. Cryst., 1999, 32, 837.

[25] (a) M. N. Burnett and C. K. Johnson, ORTEP-III - Report ORNL-6895. 1996, Oak Ridge National Laboratory, Oak Ridge, Tennessee. (b) L. J. Farrugia, ORTEP3 for Windows, J. Appl. Crystallogr. 1997, 30, 565.

[26] S. Prühs, C.W. Lehmann, A. Fürstner, Organometallics 23 (2004) 280.

[27] L. R. Hanton, P. R. Raithby, Acta Cryst., B36 (1980), 2417.

[28] K. S. Coleman, H. T. Chamberlayne, S. Turberville, M. L. H. Green, A. R. Cowley, Dalton Trans., (2003), 2917.

[29] A. J. Arduengo III, S. F. Gamper, M. Tamm, J. C. Calabrese, F. Davidson, H. A. Craig, J. Am. Chem. Soc., (1995), 117, 572.

[30] the reaction of a Grignard reagent with 1-chloro-2,6-dimethylbenzene was carried out but only gave 5 to $10 \%$ of the expected heterocoupling product, which is comparable to the results found in the literature. 
Tables and figures:<smiles></smiles>

Table 1. Crystal data and structure refinement for $\mathbf{1 c}$.

\begin{tabular}{|c|c|c|}
\hline Empirical formula & \multicolumn{2}{|l|}{$\mathrm{C}_{27} \mathrm{H}_{30} \mathrm{Br}_{3} \mathrm{~N}_{2} \mathrm{Ni} \mathrm{P}$} \\
\hline Formula weight & \multicolumn{2}{|l|}{711.94} \\
\hline Temperature & \multicolumn{2}{|l|}{ 293(2) K } \\
\hline Wavelength & \multicolumn{2}{|l|}{$0.71073 \AA$} \\
\hline Crystal system & \multicolumn{2}{|l|}{ Orthorhombic } \\
\hline \multirow[t]{2}{*}{ Space group } & $\mathrm{Pbc} \mathrm{a}$ & \\
\hline & $\mathrm{a}=13.2103(8) \AA$ & $\alpha=90^{\circ}$. \\
\hline \multirow[t]{2}{*}{ Unit cell dimensions } & $\mathrm{b}=14.6501(9) \AA$ & $\beta=90^{\circ}$. \\
\hline & $\mathrm{c}=30.0552(17) \AA$ & $\gamma=90^{\circ}$. \\
\hline Volume & \multicolumn{2}{|l|}{$5816.6(6) \AA^{3}$} \\
\hline $\mathrm{Z}$ & \multicolumn{2}{|l|}{8} \\
\hline Density (calculated) & \multicolumn{2}{|l|}{$1.626 \mathrm{Mg} / \mathrm{m}^{3}$} \\
\hline Absorption coefficient & \multicolumn{2}{|l|}{$4.862 \mathrm{~mm}^{-1}$} \\
\hline $\mathrm{F}(000)$ & \multicolumn{2}{|l|}{2832} \\
\hline Crystal size & \multicolumn{2}{|c|}{$0.23 \times 0.13 \times 0.11 \mathrm{~mm}^{3}$} \\
\hline Theta range for data collection & \multicolumn{2}{|l|}{2.86 to $23.25^{\circ}$. } \\
\hline Index ranges & \multicolumn{2}{|c|}{$-14<=\mathrm{h}<=14,-16<=\mathrm{k}<=16,-29<=1<=33$} \\
\hline Reflections collected & \multicolumn{2}{|l|}{32586} \\
\hline Independent reflections & \multicolumn{2}{|c|}{$4176[\mathrm{R}(\mathrm{int})=0.1041]$} \\
\hline Completeness to theta $=23.25^{\circ}$ & \multicolumn{2}{|l|}{$99.8 \%$} \\
\hline Absorption correction & \multicolumn{2}{|c|}{ Semi-empirical from equivalents } \\
\hline Max. and min. transmission & \multicolumn{2}{|l|}{0.5426 and 0.4162} \\
\hline Refinement method & \multicolumn{2}{|c|}{ Full-matrix least-squares on $\mathrm{F}^{2}$} \\
\hline Data / restraints / parameters & \multicolumn{2}{|l|}{4176 / 0 / 311} \\
\hline Goodness-of-fit on $\mathrm{F}^{2}$ & \multicolumn{2}{|l|}{1.236} \\
\hline Final R indices [I>2sigma(I)] & \multicolumn{2}{|c|}{$\mathrm{R} 1=0.1019, \mathrm{wR} 2=0.1407$} \\
\hline $\mathrm{R}$ indices (all data) & \multicolumn{2}{|c|}{$\mathrm{R} 1=0.1290, \mathrm{wR} 2=0.1524$} \\
\hline Largest diff. peak and hole & \multicolumn{2}{|c|}{0.716 and -0.468 e. $\AA^{-3}$} \\
\hline
\end{tabular}

Table 2. Hydrogen bonds for $\mathbf{1 c}\left[\AA\right.$ and $\left.{ }^{\circ}\right]$.

\begin{tabular}{lcccr}
\hline $\mathrm{C}-\mathrm{H} \ldots \mathrm{Br}(1)$ & $\mathrm{d}(\mathrm{C}-\mathrm{H})$ & $\mathrm{d}(\mathrm{H} \ldots \mathrm{Br})$ & $\mathrm{d}(\mathrm{C} \ldots \mathrm{Br})$ & $<(\mathrm{CHBr})$ \\
\hline $\mathrm{C}(1)-\mathrm{H}(1) \ldots \mathrm{Br}(1)^{\mathrm{i}}$ & 0.93 & 2.76 & $3.566(11)$ & 146.0
\end{tabular}




$\begin{array}{llllr}\mathrm{C}(11)-\mathrm{H}(11 \mathrm{~A}) \ldots \mathrm{Br}(1)^{\mathrm{i}} & 0.97 & 2.90 & 3.666(13) & 137.1 \\ \mathrm{C}(3)-\mathrm{H}(3) \ldots \mathrm{Br}(1)^{\mathrm{ii}} & 0.93 & 2.92 & 3.707(13) & 143.5\end{array}$

Symmetry transformations used to generate equivalent atoms:

(i) $\mathrm{x}-1 / 2, \mathrm{y},-\mathrm{z}+3 / 2$; (ii) $-\mathrm{x}+2, \mathrm{y}+1 / 2,-\mathrm{z}+3 / 2$

Table 3. Cross-coupling reactions of aryl chlorides with arylmagnesium chloride or bromide. GC yield (\%) of heterocoupling product $\mathbf{8}^{[\mathrm{aal} b \mathrm{~b}]}$

\begin{tabular}{|c|c|c|c|c|c|c|c|c|}
\hline Entry & $\mathrm{R}^{1}$ & $\mathrm{E}$ & $\mathrm{R}^{2}$ & $\mathrm{X}$ & Cat. 1a ${ }^{[\mathrm{c}]}$ & Cat. 1b ${ }^{[c]}$ & Cat. 1c ${ }^{[c]}$ & $\operatorname{IPr} / \mathrm{Ni}(\mathrm{acac})_{2}{ }^{[\mathrm{d}]}$ \\
\hline 1 & $\mathrm{H}$ & $\mathrm{N}$ & $\mathrm{H}$ & $\mathrm{Cl}$ & $>99$ & $>99$ & $>99$ & $>99$ \\
\hline 2 & $4-\mathrm{CF}_{3}$ & $\mathrm{C}$ & $\mathrm{H}$ & $\mathrm{Cl}$ & 37 & 53 & 29 & 96 \\
\hline 3 & $4-\mathrm{CH}_{3}$ & $\mathrm{C}$ & $\mathrm{H}$ & $\mathrm{Cl}$ & 86 & 96 & 63 & 81 \\
\hline 4 & $4-\mathrm{OCH}_{3}$ & $\mathrm{C}$ & $\mathrm{H}$ & $\mathrm{Cl}$ & 95 & 92 & 80 & 71 \\
\hline 5 & $2-\mathrm{CH}_{3}$ & $\mathrm{C}$ & $\mathrm{H}$ & $\mathrm{Cl}$ & 78 & 82 & 23 & 73 \\
\hline 6 & bromomesitylene & $\mathrm{C}$ & $\mathrm{H}$ & $\mathrm{Cl}$ & 4 & 3 & 7 & 5 \\
\hline 7 & $\mathrm{H}$ & $\mathrm{N}$ & $4-\mathrm{OCH}_{3}$ & $\mathrm{Br}$ & $>99$ & $>99$ & $>99$ & $>99$ \\
\hline 8 & $4-\mathrm{CF}_{3}$ & $\mathrm{C}$ & $4-\mathrm{OCH}_{3}$ & $\mathrm{Br}$ & 36 & 33 & 42 & $>99$ \\
\hline 9 & $\mathrm{H}$ & $\mathrm{C}$ & $4-\mathrm{OCH}_{3}$ & $\mathrm{Br}$ & 99 & 98 & 76 & 93 \\
\hline 10 & $4-\mathrm{CH}_{3}$ & $\mathrm{C}$ & $4-\mathrm{OCH}_{3}$ & $\mathrm{Br}$ & 92 & 87 & 89 & 88 \\
\hline 11 & $2-\mathrm{CH}_{3}$ & $\mathrm{C}$ & $4-\mathrm{OCH}_{3}$ & $\mathrm{Br}$ & 48 & 87 & 12 & 77 \\
\hline
\end{tabular}

${ }^{\text {a] }}$ For the meaning of $\mathrm{R}^{1}, \mathrm{R}^{2}$, $\mathrm{E}$ and $\mathrm{X}$ and for the nature of the possible reaction products, see Scheme 3 .

${ }^{[b]}$ Conditions: 1.0 eq aryl halide, 1.5 eq aryl Grignard, $3 \mathrm{~mol} \% \mathbf{1 a - c}, \mathrm{THF}, 25^{\circ} \mathrm{C}, \mathrm{t}=18 \mathrm{~h}$.

${ }^{[c]}$ GC yield using diethyleneglycol-di-n-butylether as the internal standard. The relative yields in percent are normalized to the reagent in $\operatorname{defect}(\mathbf{6}): \mathbf{6}+\mathbf{8}+\mathbf{9}+\mathbf{1 0}=100$.

[d] Ref. [18].

Table 4. Detailed results of cross-coupling reactions with phenylmagnesium chloride. ${ }^{[a]}$

\begin{tabular}{ccccccc}
\hline Entry & $\mathrm{R}$ & $\mathrm{E}$ & Cat. 1a & Cat. 1b & Cat. 1c & IPr/Ni(acac) \\
\hline 1 & $\mathrm{H}$ & $\mathrm{N}$ & $100 / 0 / 0 / 0 / 6$ & $100 / 0 / 0 / 0 / 17$ & $100 / 0 / 0 / 0 / 21$ & $100 / 0 / 0 / 0 / 4$ \\
2 & $4-\mathrm{CF}_{3}$ & $\mathrm{C}$ & $37 / 63 / 0 / 0 / 30$ & $53 / 47 / 0 / 0 / 30$ & $29 / 71 / 0 / 0 / 27$ & $96 / 4 / 0 / 0 / 4$ \\
3 & $4-\mathrm{CH}_{3}$ & $\mathrm{C}$ & $86 / 2 / 5 / 7 / 17$ & $96 / 2 / 1 / 1 / 10$ & $63 / 32 / 4 / 1 / 15$ & $81 / 7 / 3 / 9 / 11$ \\
4 & $4-\mathrm{OCH}_{3}$ & $\mathrm{C}$ & $95 / 4 / 0 / 1 / 19$ & $92 / 6 / 1 / 1 / 22$ & $80 / 18 / 1 / 1 / 19$ & $71 / 19 / 1 / 9 / 16$ \\
5 & $2-\mathrm{CH}_{3}$ & $\mathrm{C}$ & $78 / 10 / 12 / 0 / 24$ & $82 / 11 / 7 / 0 / 20$ & $23 / 67 / 10 / 0 / 22$ & $73 / 9 / 10 / 8 / 15$ \\
6 & bromomesitylene & $\mathrm{C}$ & $4 / 64 / 32 / 0 / 27$ & $3 / 71 / 26 / 0 / 23$ & $7 / 53 / 40 / 0 / 26$ & $5 / 80 / 15 / 0 / 12$ \\
\hline
\end{tabular}

[a] The product distribution is given as 8/6/9/10/11; the amount of 10 was approximated by comparison of the peak integrations. 
Table 5. Detailed results of cross-coupling reactions with 4-anisylmagnesium bromide. ${ }^{[a]}$

\begin{tabular}{ccccccc}
\hline Entry & $\mathrm{R}$ & $\mathrm{E}$ & Cat. 1a & Cat. 1b & Cat. 1c & $\operatorname{IPr} / \mathrm{Ni}(\mathrm{acac})_{2}$ \\
\hline 7 & $\mathrm{H}$ & $\mathrm{N}$ & $100 / 0 / 0 / 0 / 7$ & $100 / 0 / 0 / 0 / 6$ & $100 / 0 / 0 / 0 / 10$ & $100 / 0 / 0 / 0 / 1$ \\
8 & $4-\mathrm{CF}_{3}$ & $\mathrm{C}$ & $36 / 63 / 1 / 0 / 17$ & $33 / 66 / 1 / 0 / 15$ & $42 / 57 / 1 / 0 / 16$ & $100 / 0 / 0 / 0 / 8$ \\
9 & $\mathrm{H}$ & $\mathrm{C}$ & $99 / 0 / 0 / 1 / 4$ & $98 / 1 / 0 / 1 / 6$ & $76 / 23 / 0 / 1 / 4$ & $93 / 3 / 3 / 1 / 16$ \\
10 & $4-\mathrm{CH}_{3}$ & $\mathrm{C}$ & $92 / 7 / 0 / 1 / 5$ & $87 / 11 / 1 / 0 / 3$ & $89 / 10 / 1 / 0 / 5$ & $88 / 5 / 4 / 3 / 15$ \\
11 & $2-\mathrm{CH}_{3}$ & $\mathrm{C}$ & $48 / 45 / 6 / 1 / 6$ & $87 / 9 / 3 / 1 / 5$ & $12 / 83 / 5 / 0 / 5$ & $77 / 20 / 0 / 3 / 10$ \\
\hline
\end{tabular}

[a] The product distribution is given as 8/6/9/10/11; the amount of $\mathbf{1 0}$ was approximated by comparison of the peak integrations.

Figure 1. Proposed structures of $\mathrm{Ni}(\mathrm{II})$ carbenic complexes from 1a: monomer (cis coordination) and dimer (trans coordination).

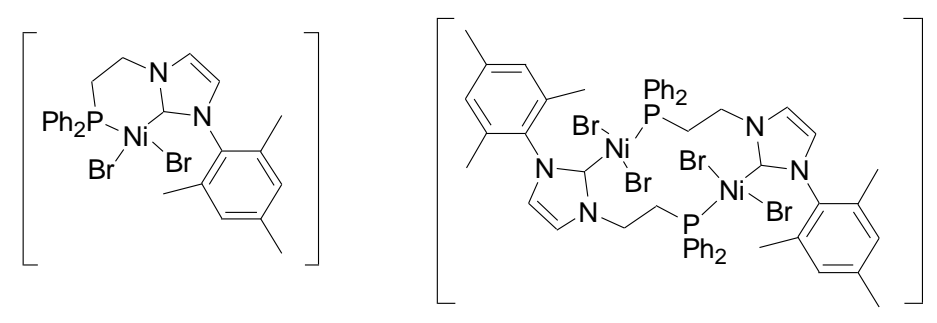

Figure 2. Molecular view of compound 1c with atom labelling scheme. $\mathrm{H}$ atoms have been omitted for clarity. Selected bond lengths $(\AA)$ and bond angles $\left(^{\circ}\right)$ : Ni(1)-P(1) 2.330(3); $\mathrm{Ni}(1)-\mathrm{Br}(1) \quad 2.3723(18) ; \quad \mathrm{Ni}(1)-\mathrm{Br}(2) \quad 2.3774(19) ; \quad \mathrm{Ni}(1)-\operatorname{Br}(3) \quad 2.3518(19) ; \quad \mathrm{N}(1)-\mathrm{C}(11)$ 1.476(13); N(1)-C(1) 1.327(12); N(1) C(3) 1.365(14); N(2)-C(1) 1.313(12); N(2)-C(2) 1.362(14); N(2)-C(211) 1.448(13); C(2)-C(3) 1.326(16); P(1)-Ni(1)-Br(1) 100.52(10); P(1)$\mathrm{Ni}(1)-\mathrm{Br}(2)$ 105.26(9); $\mathrm{P}(1)-\mathrm{Ni}(1)-\mathrm{Br}(3)$ 110.73(10); $\mathrm{Br}(1)-\mathrm{Ni}(1)-\operatorname{Br}(2)$ 106.07(8); $\mathrm{Br}(1)-$ $\mathrm{Ni}(1)-\mathrm{Br}(3)$ 112.77(8); $\mathrm{Br}(2)-\mathrm{Ni}(1)-\mathrm{Br}(3)$ 119.57(8); N(1)-C(1)-N(2) 108.7(10); C(1)-N(1)$\mathrm{C}(3) \quad 107.7(10) ; \quad \mathrm{C}(1)-\mathrm{N}(2)-\mathrm{C}(2) \quad 108.7(10) ; \quad \mathrm{N}(1)-\mathrm{C}(3)-\mathrm{C}(2) \quad 107.8(11) ; \quad \mathrm{N}(2)-\mathrm{C}(2)-\mathrm{C}(3)$ 107.1(11).

(TIFF file)

Figure 3. Conversion of 4-chloroanisole vs time with 1a-c (Table 3, entry 4). 


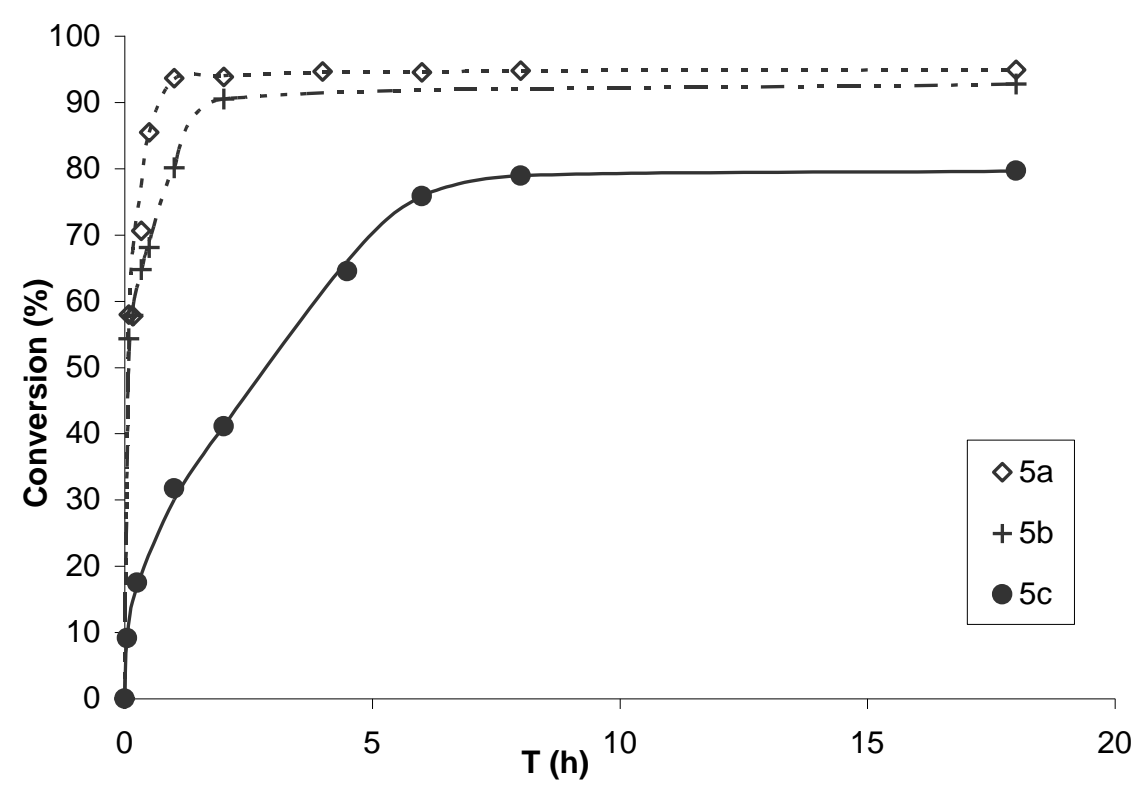

Figure 4. Conversion of 4-chlorotoluene vs time with 1a-c (Table 3, entry 10) and comparison with the $\mathrm{Ni}(\mathrm{acac})_{2} / \mathrm{IPr}$ system.

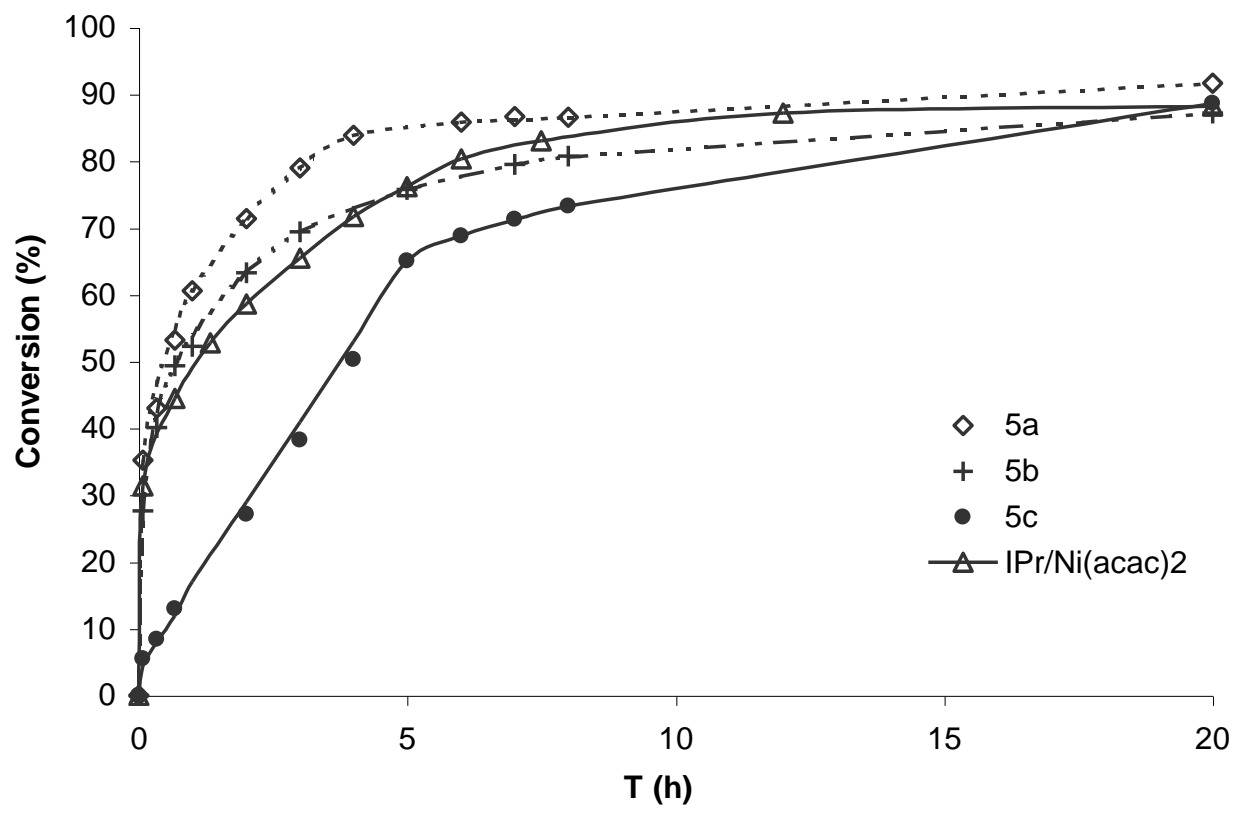

Figure 5. Conversion of 4-chlorobenzotrifluoride $v s$ time with $\mathbf{1 a}$. 


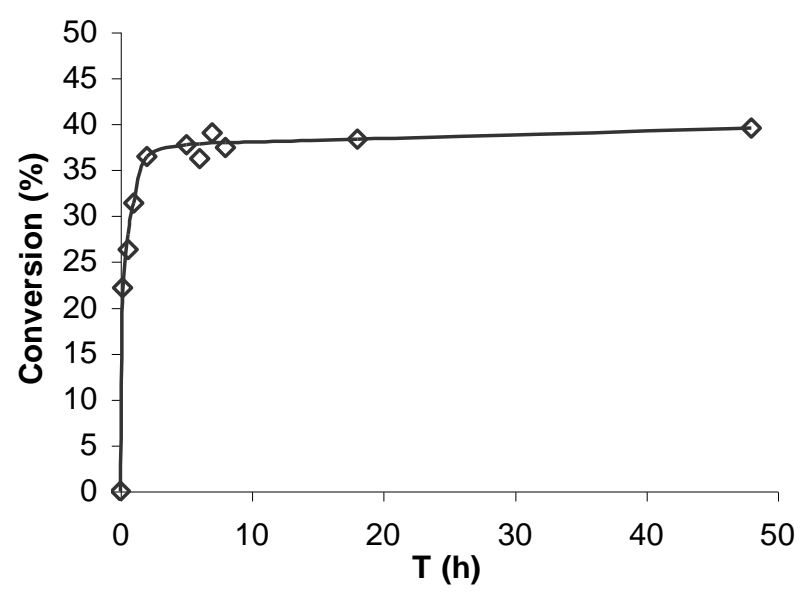

Scheme 1. Reagents and conditions: (i) 2-bromoethanol, toluene, $120{ }^{\circ} \mathrm{C}, 18 \mathrm{~h}$; (ii) 3-bromo1-propanol, toluene, $120{ }^{\circ} \mathrm{C}, 15 \mathrm{~h}$; (iii) $\mathrm{PBr}_{3}, \mathrm{CH}_{2} \mathrm{Cl}_{2}, 0{ }^{\circ} \mathrm{C}, 20 \mathrm{~h}$; (iv) $\mathrm{HPPh}_{2}, t$-BuOK, DMSO, rt, 2 h (5a,b), 15 h (5c).

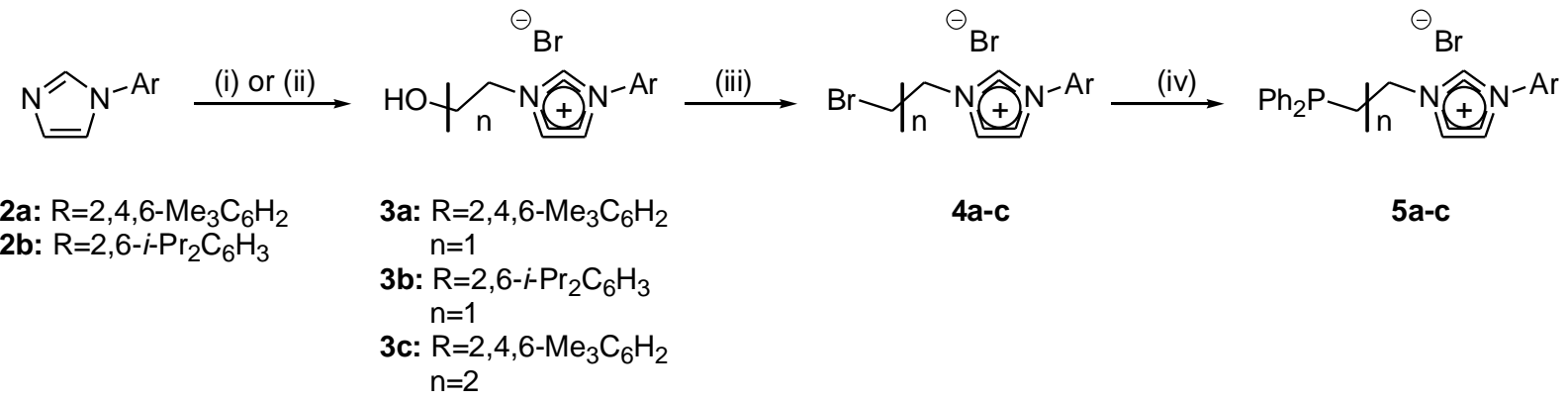

Scheme 2. Reagents and conditions: (i) $\mathrm{NiBr}_{2}(\mathrm{DME}), \mathrm{THF}, \mathrm{rt}, 30 \mathrm{~min}$ to $1 \mathrm{~h}(\mathbf{1 a}, \mathbf{b})$; (ii) $\mathrm{NiBr}_{2}(\mathrm{MeCN})_{2}$, THF, rt, 1h (1c).

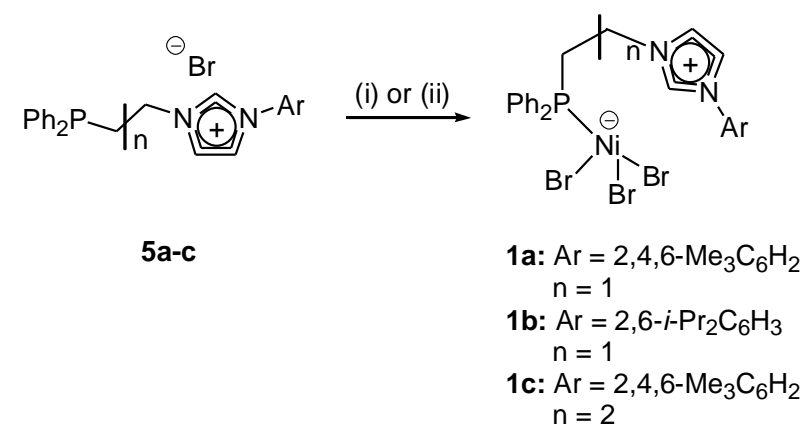

Scheme 3. Reagents and products for the catalytic Kumada-Corriu reaction (for the results, see Tables 3, 4 and 5). 


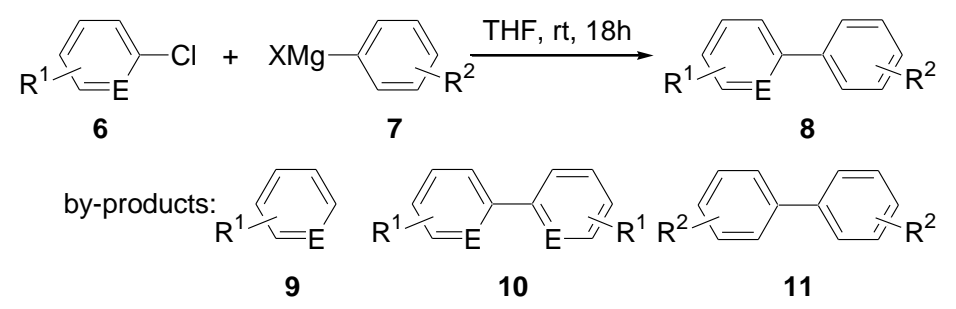

